
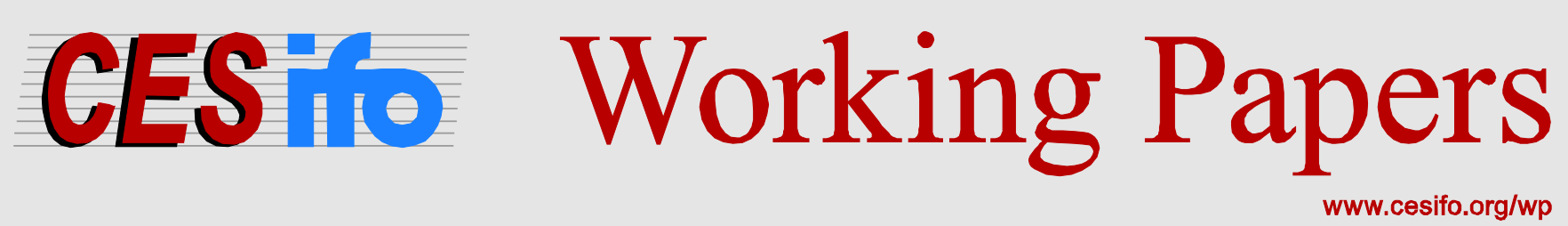

\title{
Why Do Trade Finance Gaps Persist: Does it Matter for Trade and Development?
}

\author{
Marc Auboin \\ Alisa DiCaprio
}

CESIFO WORKING PAPER NO. 6425

CATEGORY 8: TRADE POLICY

MARCH 2017

An electronic version of the paper may be downloaded

- from the SSRN website:

- from the RePEc website:

- from the CESifo website:

wWw.SSRN.com

www.RePEc.org

www.CESifo-group.org/wp 


\title{
Why Do Trade Finance Gaps Persist: Does it Matter for Trade and Development?
}

\begin{abstract}
Trade finance shortfalls now appear regularly. Does this matter for trade expansion and economic development in developing countries? Global trade finance has resumed following the 2009 global financial crisis. However, the pattern of recovery has been uneven across countries and categories of firms. The recovery has been robust for the main routes of trade and for large trading companies. By contrast, access to trade finance remains costly and scarce in countries which have the strongest potential for trade expansion. The policy response to this problem depends on whether this represents a market failure, or a new global equilibrium. We introduce new data from a global survey of firms to argue that real shortfalls are exacerbated by perception gaps in a way that has enabled market failures to persist. This has troubling implications most directly through its effect on the ability for small firms to benefit from the reallocation of production and investment within global supply chains.
\end{abstract}

JEL-Codes: F130, F340, F360, O190, G210, G320.

Keywords: international financial institutions, coherence, G-20, financial crisis, trade and development, trade finance, economic development.

Marc Auboin

Economic Research and Statistics Division

World Trade Organization

Geneva / Switzerland

Marc.Auboin@wto.org

\author{
Alisa DiCaprio \\ Asian Development Bank Institute \\ Tokyo / Japan
}

All views expressed are those of the authors and cannot be attributed to the WTO Secretariat, WTO Members, and the Asian Development Bank. The paper is still very much work-inprogress. 


\section{INTRODUCTION}

Trade finance shapes export opportunities. The networks that define cross-border commerce all entail some form of finance. For countries where trade finance functions well, it enables firms which would otherwise be considered too risky, to link into expanding global value chains and thus contribute to employment and productivity growth. But what about markets where trade finance supply does not meet demand? In 2016, ADB estimated a global trade finance gap of \$1.6 trillion dollars. It is not evenly distributed. 337 financial institutions that evaluate applications for trade finance report rejection rates of $56 \%$ for small and medium sized enterprises and $44 \%$ for firms in Asia and the Pacific. This is perplexing, given that trade finance is one of the safest forms of finance, in which less than $1 \%$ of transactions go into default.

Advances in measuring and understanding the impact of trade finance on trade flows was one of the key outcomes of the 2009 global financial crisis. The crisis offered a stark discontinuity in the availability of trade finance that moved the literature on credit rationing forward. We now have a clearer understanding of the impact of trade finance on trade flows (e.g., Ahn et al, 2011; Chor and Monova, 2012) and the role of bank characteristics on the activities of firms associated with them (e.g., Amiti and Weinstein, 2011; Chodorow-Reich, 2014).

By 2011, trade finance conditions returned to normal in most markets. However, the structural difficulties of poor countries, emerging markets and countries suffering sovereign default in accessing trade finance did not disappear. In part this is expected - recovery from financial crisis lags in weaker economies (Freund, 2009). But it also underscores how financial deepening in developing countries over time has not been accompanied by advances in financial inclusion (Dabla-Norris et al, 2015).

It is this second issue which motivates this paper. We know that the various paths countries can take to reach financial sector development have different long run growth impacts at the country level (Bordo and Meissner, 2015). And we know that trade finance impacts trade flows, so there is a clear link between trade finance and development. But what does this look like on the ground? And how do rationed populations react to persistent unmet demand?

The literature on the broader issue of access to finance offers indicative directions for consideration. At the firm level, access to finance during the firm life cycle affects outcomes growth, employment, and survival (Clementi and Hopenhayn, 2006). We also know that finance affects the decision to export (Berman and Hericort, 2010). Following this, we direct our attention to how firms react to shortfalls in access to trade finance in three areas: trade outcomes, capital allocation, and employment characteristics.

To explore our hypotheses we employ data from a second ADB survey which asked 791 firms from 96 countries to detail what happens to their businesses under shortfall conditions. We use their responses to understand how firms behave after a transaction is rejected. This includes a discussion of the particular problems faced by women-led firms. We then go one step further to consider the solution that has received the most attention in the last few years - digitization of trade finance. The ADB surveys provide some insight into two categories of digitization that might impact firm outcomes. First is digitization of bank processing, and the second is financial technologies (fintech). 
This lets us explore the question of whether digitization of the sector is addressing exclusion of countries and client groups that lack sufficient access to traditional trade finance.

The data shows that exclusion of SMEs is a problem that extends beyond their access to finance. The issue of access to basic finance is the primary question being examined in the policy sphere. But we show that exclusion remains a problem even beyond the initial step of being banked. All of the firms included in the ADB survey have a banking relationship. But they still experience shortfalls in trade finance. This issue is particularly relevant in the current environment of slow trade growth and shifting supply chains. This is because under-supply of trade finance also affects the opportunities for countries to link into global value chains. The opportunity for lower-cost economies to capture market share is open. Countries in developing Asia and Africa are poised to take advantage of the relocation of apparel and garments manufacturing from the PRC (Zhang et al, 2015), but new players require trade finance, as up to $80 \%$ of global exports are supported by some sort of financing or credit insurance.

This work extends two key literatures. First, it deepens the credit rationing literature to include additional detail on the situation where rationing does not resolve after the shock has ended. Second, it extends the rich literature on access to finance by looking at the next level of firms which have made the initial link to finance, and are now seeking more sophisticated instruments to support production. One benefit of using a global survey as a baseline to detail the causes and impacts of trade finance gaps is to underscore that negative impacts are global. While gaps are more acute in emerging markets, SMEs located in countries at every income level and in every geographic region face the same difficulties and exhibit the same compensating behaviours.

To understand the development impacts of trade finance shortfalls we begin in Section 1 by presenting general evidence that trade finance gaps reflect a structural market failure. This implies that narrowing gaps can be accomplished without negative profit implications in the sector. Section 2 substantiates the argument by using the survey of financial institutions to show that the reasons for undersupply are not wholly determined by risk considerations. The main section is Section 3 which looks into the development impacts of trade finance shortfalls. In exploring our three hypotheses we detail the compensating behaviours that firms adopt when trade finance demand is unmet. Finally, Section 4 concludes with an extended discussion of digitization in the trade finance sector.

\section{MARKET FAILURE IN TRADE FINANCE}

The primary question raised by the existence of pools of persistent unmet demand is: if the trade finance market is so safe, why is there any under-supply at the lower end of the market? Trade finance is mostly short-term in nature and yields limited returns in the main trade corridors. Therefore, the disconnect between the higher end of the trade finance market - yielding cheap liquidity - and the lower end of the market in which liquidity is scarce and prices high, raises suspicion of market segmentation and failure.

Table1 illustrates the feature of regional trade finance markets that motivates our study into the development impacts of shortfalls. In all cases, default rates indicate low risk in trade finance. This holds across regions. We can see for example that the underlying transaction default rates for Africa $(0.39 \%)$ compare favourably to that in European markets $(0.38 \%)$. However, the rejection rates for 
trade finance transaction proposals imply that financial institutions treat transactions in emerging markets as high risk. The gap between the perception and actual level of risk of the transactions is clearly one of the main causes of the rationing to which certain regions are subject. This gap tends to increase in periods of crisis, even though the payment record does not deteriorate that much.

Table 1. Actual risk of trade finance (default rates) vs. perception of risk (rejection rates for trade finance requests)

\begin{tabular}{|l|c|c|c|}
\hline & $\begin{array}{l}\text { Transaction default } \\
\text { rate (2007-2014) }\end{array}$ & $\begin{array}{l}\text { Rejection rate on trade } \\
\text { finance transactions (2014) }\end{array}$ & $\begin{array}{l}\text { Financial } \\
\text { depth (2014) }\end{array}$ \\
\hline Africa & $0.39 \%$ & $19 \%$ & $46 \%$ \\
\hline Middle East & $2.43 \%$ & $29 \%$ & $48 \%$ \\
\hline APAC & $0.29 \%$ & \multirow{2}{*}{$8 \%$} & $130 \%$ \\
\hline $\begin{array}{l}\text { Central and South } \\
\text { America }\end{array}$ & $0.50 \%$ & & $51 \%$ \\
\hline United States & $0.0 \%$ & $17 \%$ & $195 \%$ \\
\hline CIS & $1.28 \%$ & $12 \%$ & $55 \%$ \\
\hline Europe & $0.38 \%$ & & $100 \%$ \\
\hline
\end{tabular}

Sources: transaction default rate from ICC, 2015; rejection rate from ADB, 2014; Financial depth from World Bank Global Financial Development Database (GFDD).

NOTE: financial depth is defined as domestic private credit to the real sector by deposit money banks as a percentage of local currency GDP.

While the magnitude of unmet demand in emerging economies and developing regions is debatable, surveys consistently produce results showing that gaps persist. In Asia and Africa, surveys that cover 2011-2015 show persistent unmet demand in both regions. Globally, unmet global demand for trade finance may have been as high as US\$ 1.6 trillion in 2015 (ADB, 2016). In Asian developing economies alone, the estimated shortage is US\$ 692 billion.

Figure 1. Distribution of proposed transactions and rejections (by region, \%)

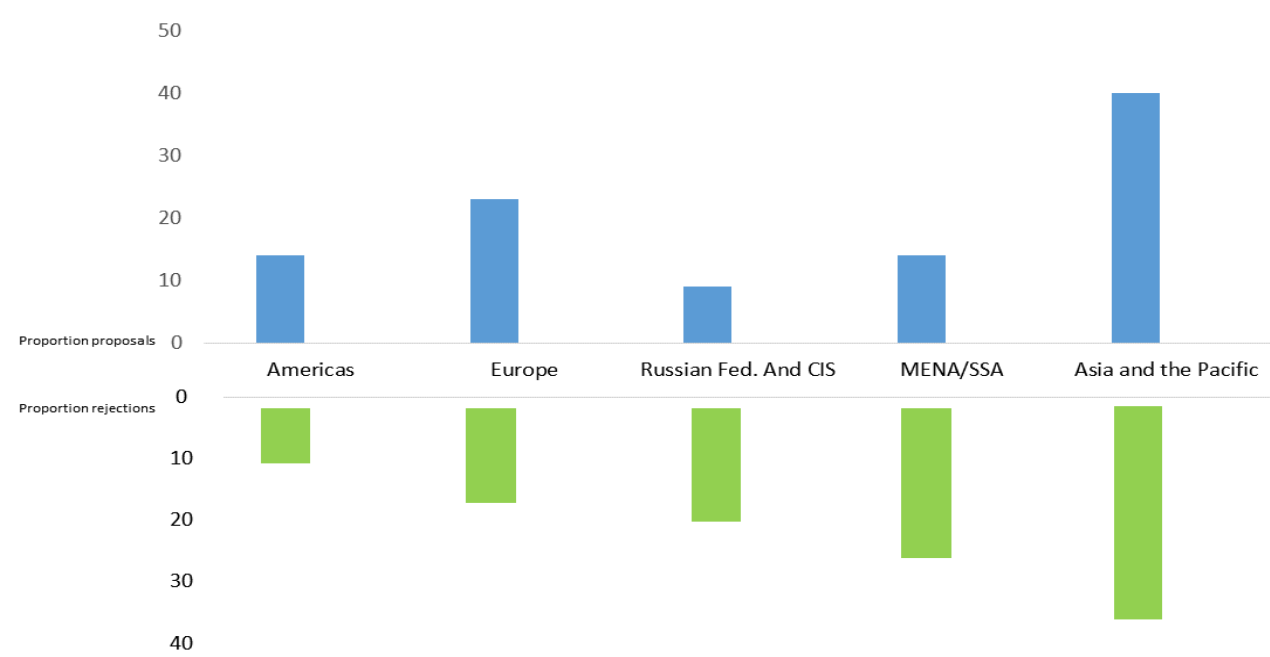

Source: ADB Trade Finance Gaps, Growth, and Jobs Survey 2016 
In Africa, the African Development Bank estimates that the market for bank-intermediated trade finance was between US\$330-350 billion. They estimate the value of unmet demand for trade finance in Africa at US\$ 110 billion in 2011 and US\$ 120 billion in 2012 (AfDB, 2014).

Regional shortfalls are also reflected in data on correspondent relationships. These are the bank-tobank connections that are needed to facilitate cross-border commercial transactions. One way to measure these relationships is by the number of messages that are passed between banks. Data from the Bank of International Settlements (BIS) shows that there is an increasing concentration in correspondent banking (BIS, 2016), while Figure 2 provides evidence that the number of corresponding relationship has continued to drop in 2015.

Figure 2. Regional changes in correspondent relationships $(2014,2015)$

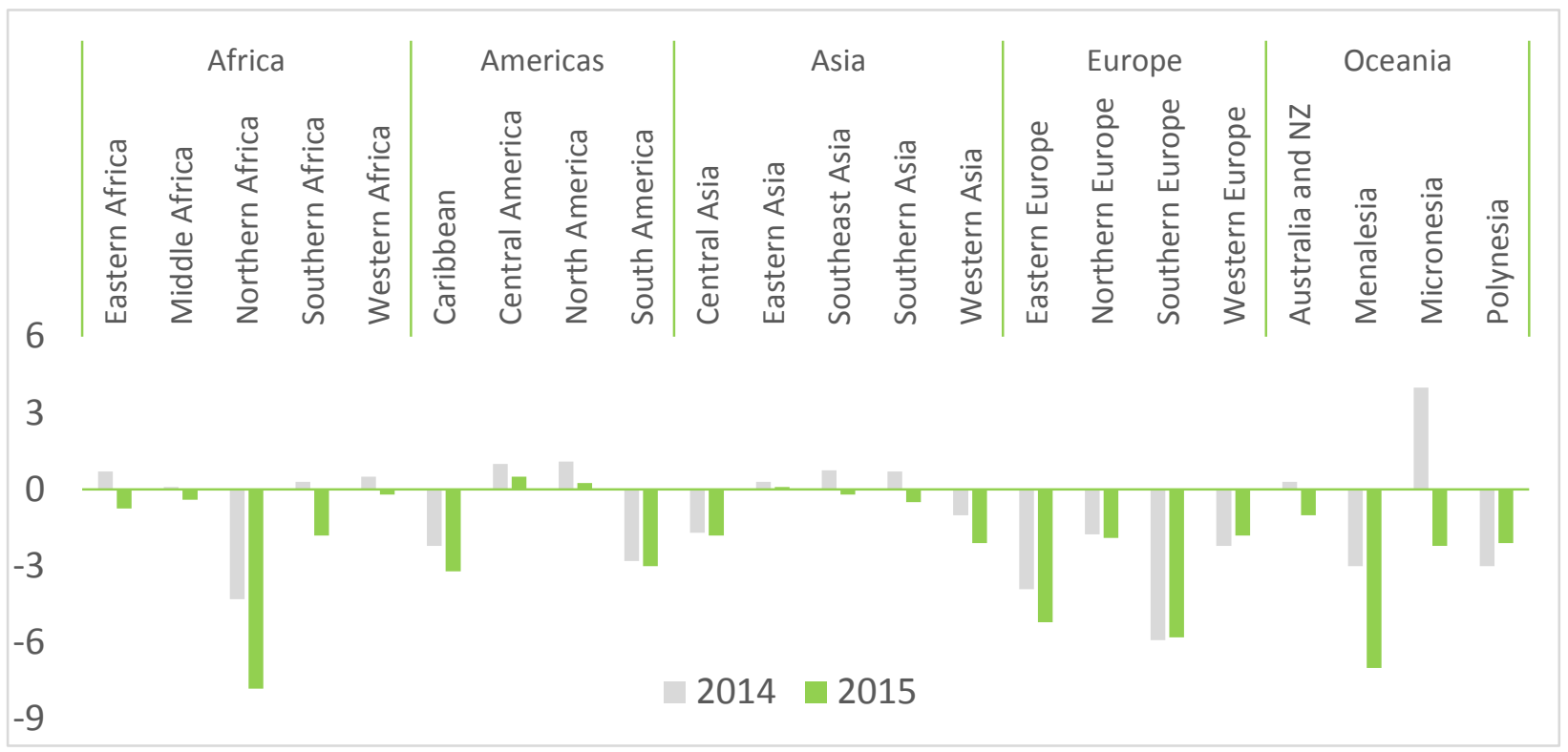

Source: Swift Watch, cited in BIS (2016) 
Market entry by financial institutions has been more cautious and a large number of correspondent banking relationships have disappeared. In this environment, there is a concern that de-risking affects the pace at which the benefits of global trade spread into new countries, in particular lowincome economies where the local banking sector may not be equipped, technically or financially, to respond to the new demand from small producers and traders.

Policy makers have acknowledged the problem this poses. In 2016, the IMF suggested that lower volume jurisdictions have become less attractive because of regulatory concerns, including newly imposed sanctions and increasing costs emanating from new standards for anti-money laundering and related checks. ${ }^{2}$ They concluded that the withdrawal of commercial banking relationships had reached a "critical level" that could "disrupt financial services and cross-border flows, including trade finance and remittances, potentially undermining financial stability, inclusion, growth and development goals."

How does this evidence that certain regions are consistently and increasingly excluded from trade finance fit with what we know about trade finance markets? First we turn to the question of risk.

\subsection{TRADE FINANCE IS LOW RISK}

Trade finance markets have been growing along with international trade flows in recent decades. For the most part, markets cleared relatively smoothly, notably in mature, developed countries markets. Unlike credit derivatives and other complex financial products, trade finance instruments have not been at the origin of financial crises. Rather, their supply has been hit by the contagion of financial crises originating in other segments of the financial industry.

The size of the bank-intermediated short-term trade finance market was estimated at \$6.5-8 trillion in 2011 (BIS, 2014b). Considered in its widest definition, the market is very large - certainly well above US\$ 14 trillion annually out of US\$ 18 trillion of exports (or imports) in 2011 However, there is no single, comprehensive source of statistics allowing for an evaluation of the exact composition and size of trade finance markets.

Trade finance is a particularly safe form of finance since it is underwritten by collateral and documented credit operations. The low risk nature of short-term trade finance is supported by data collated by the ICC which shows the average transaction default rate on short-term international trade credit is 0.021 per cent, of which 57 per cent is recovered though the sale of the underlying asset. $^{3}$

The risk involved in short term trade finance does not vary significantly by geographic region. Table 2 statistics on default are averages with low deviations from the mean. The average takes into account transactions in developed, developing and least-developed parts of the world. Each transaction has two sides (the exporter and importer); North-North trade only account for $40 \%$ of world trade). Given the weight of developing countries in the averaging, the regional dispersion of results is not very large.

\footnotetext{
${ }^{2}$ The Withdrawal of Correspondent Banking Relationships: A Case for Policy Action (IMF, 2016)

${ }^{3}$ This would imply a transaction-level economic loss rate of approximately of $0.012 \%$ (i.e. $0.021 \% \times 57 \%$ ) for short-term trade finance transactions. By comparison, the average level of non-performing loans for main banks in the US over the past twenty years has been 3\% (World Bank data).
} 
Table 2. Risk characeristics of short-term trade finance products (global, 2008-11)

\begin{tabular}{|c|c|c|c|c|c|}
\hline CATEGORY & $\begin{array}{l}\text { Transaction } \\
\text { default rate }\end{array}$ & $\begin{array}{l}\text { Implied } \\
\text { maturity } \\
\text { (days) }\end{array}$ & $\begin{array}{l}\text { Recovery } \\
\text { rate }^{1}\end{array}$ & $\begin{array}{l}\text { Defaulted } \\
\text { trans-action } \\
\text { loss rate }^{2}\end{array}$ & $\begin{array}{l}\text { Specific } \\
\text { transaction- } \\
\text { level loss rate }\end{array}$ \\
\hline Import L/Cs & $0.020 \%$ & 80 & $71 \%$ & $42 \%$ & $0.008 \%$ \\
\hline Export confirmed L/Cs & $0.016 \%$ & 70 & $40 \%$ & $68 \%$ & $0.011 \%$ \\
\hline Loans for import & $0.016 \%$ & 110 & $45 \%$ & $64 \%$ & $0.010 \%$ \\
\hline Loans for export: Bank risk & $0.029 \%$ & 140 & $32 \%$ & $73 \%$ & $0.021 \%$ \\
\hline Loans for export: Corporate risk & $0.021 \%$ & 70 & $51 \%$ & $57 \%$ & $0.012 \%$ \\
\hline Performance guarantees & $0.034 \%$ & 110 & $18 \%$ & $85 \%$ & $0.029 \%$ \\
\hline Total & $0.021 \% *$ & 90 & $52 \%$ & $57 \%$ & $0.012 \% * *$ \\
\hline
\end{tabular}

${ }^{1}$ Observed recoveries as a percentage of defaulted exposure across products.

${ }^{2}$ Estimated economic loss rate as a percentage of defaulting exposure after discounting and costs.

* Over 2008-11, the average observed annual issuer-weighted corporate default rates for Aa-rated customers was $0.14 \%$.

** The total average and the product-level annual transaction-level loss compare favourably with the average observed annual credit loss rate for Moody's customers over the same period of $1.49 \%$.

Source: ICC (2013), pp. v, 23.

The dependence on (traditional) trade finance also varies by region. Asia and the Pacific are highly reliant on traditional trade finance, while Latin America has a lower dependence. This is shown both in bank surveys as well as in SWIFT data on letters of credit transactions. In part, this reflects world trade shares; however it is also indicative of the perceived risk of doing business with different regions.

Table 3. Regional dependence on letters of credit (MT700 messages received \%)

\begin{tabular}{|l|c|c|}
\hline & $\begin{array}{c}2015 \text { share global } \\
\text { export LCs }\end{array}$ & $\begin{array}{c}2015 \text { regional } \\
\text { world trade share }\end{array}$ \\
\hline Asia and the Pacific & $70 \%$ & $33 \%$ \\
\hline North America & $13 \%$ & $15 \%$ \\
\hline Middle East & $4 \%$ & $3 \%$ \\
\hline Africa & $2 \%$ & $1.4 \%$ \\
\hline Central and Latin America & $1 \%$ & $5.7 \%$ \\
\hline
\end{tabular}

Sources: Export Letters of Credit SWIFT 2016, world trade share from UN Comtrade 2016

The pooling of unmet demand in certain regions could simply reflect low financial sector development in dynamically growing regions, which itself is not a market failure. Subsection 1.2 continues to build the case by highlighting that the ability of firms to trade depends heavily on their access to trade finance. And where more trade finance is available, trade increases measurably.

\subsection{TRADE FINANCE DIRECTLY IMPACTS TRADE}


The assumption underlying this paper is that trade finance impacts development. We are able to start here as a result of a substantial literature showing that trade finance impacts trade. This links then to the literature on trade and development. In this section, we review what we know about the relationship between trade finance and trade.

Until the global financial crisis in 2008-2009, international trade finance was not typically incorporated into trade analysis. International trade models often assume perfect capital markets and efficient allocation of credit resources. In most models, the financing of trade held no particular role, and no spill-over effects was assumed from credit markets to the supply of traded goods. The literature on inter-firm trade credit, such as on supplier credits and cash-in-advance, did exist but it had not yet expanded into its international dimension and impact on trade flows and development (see Fisman and Love, 2002 for a review of that literature).

There are three strands of the literature that highlight the importance of the supply of trade finance for international trade transactions. The first is macro level studies that connect trade credit and trade flows. The OECD (Korinek et al. 2010) found a strong statistical relationship between insured short-term trade credit, as a proxy for total trade finance, and trade flows. When extending the same dataset over a full cycle, 2005-2012, a strong correlation is found between insured trade credit and trade flows (Figure 3)

Figure 3. The relation between imports and insured trade credits (million US\$)

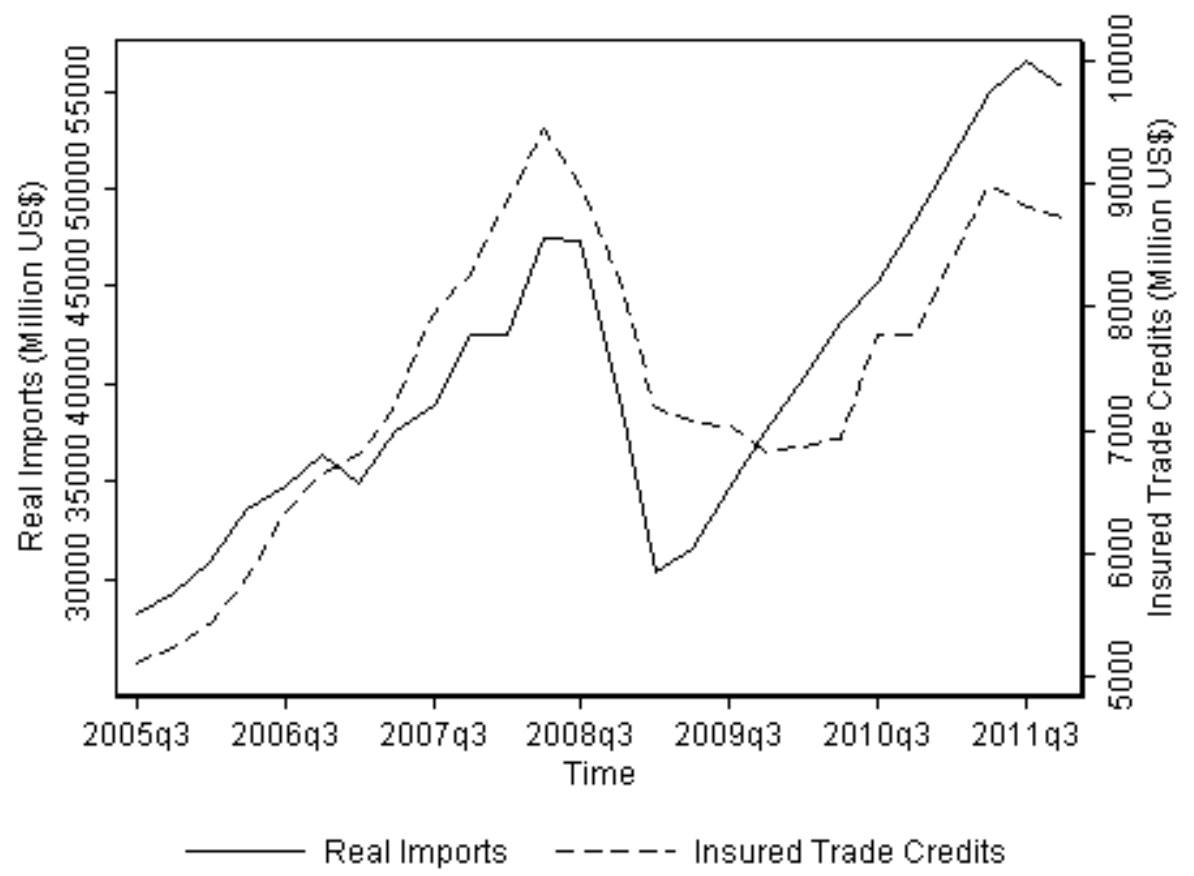

Source: Auboin and Engemann, 2014

Auboin and Engemann (2014) use a two-stage approach to link global economic and financial conditions (GDP and liquidity) and trade credit availability, in the first stage; and trade credit availability and imports in the second. This approach was aimed at avoiding endogeneity problems linked to reverse causality between trade credit and trade, as the volume of trade demand impacts on the demand for trade credit, and trade credit availability impacts trade as well. Trade credit was 
found to be a significant and robust determinant of imports, with elasticities being stable and robust to tests around $0.3-0.4 \%$.

A second strand of the literature looks at the 2009 global financial crisis. Amiti and Weinstein (2011) find that in Japan, the trade finance channel accounted for about $20 \%$ of the decline in Japanese exports during the financial crisis of 2008-2009. One reason is because exporters, more than any other producers, are reliant on trade credit and guarantees. Chor and Manova (2012) found that credit conditions were one important channel through which the crisis led to the collapse in trade. Countries with tighter credit markets, measured by their interbank interest rates, exported less to the US during the recent financial crisis. This effect is especially strong for financially vulnerable industries. Bricongne and al. (2012) found that, in France, sectors which were highly dependent on external finance had been most severely hit by the financial crisis and experienced the largest drop in their export activity. Small and large firms, at the two end of the spectrum of the 50,000 exporters' dataset, have been most affected by the shortage in trade credit.

A third strand explores the case of developing countries in various crisis situations. lacovone and Zavacka (2009) found that export-oriented sectors are more exposed to banking crises than other sectors. During local banking crises, exporters may still find access to trade credit from their international trading partners. But, in times of worldwide financial crisis, exporters are particularly vulnerable. Love et al. (2007) analysed the use of trade credits by firms in Asia during the Asian financial crisis, and Mexican firms after the 1994 Peso devaluation. They found that in times of liquidity shortages, firms which are cut out from bank financing cannot find a substitute in the form of trade credit granted by other firms or bank credit.

The short message is that trade finance matters for trade. Where provision is sufficient, it benefits trade (e.g. Auboin et al 2016), and where it is insufficient, there is a negative effect on trade (e.g. Amiti and Weinstein 201). Particularly during financial crisis, empirical evidence seems to suggest that a lack of trade finance has been one of the reasons for the decline in trade.

Trade finance gaps however do not only exist at a geographic or regional level. The second layer of trade finance gaps occurs at the client level. This shortfall - specifically for SMEs - holds across countries.

\subsection{TRADE FINANCE GAPS AT THE SME LEVEL}

The market failure argument has a second dimension in the story about access to trade finance. Until now, we have focused on country level with certain emerging regions being impacted more than we would expect. But surveys also show that certain client groups are consistently undersupplied regardless of their location. This is similar to the story about SME financing gaps more generally, but in this case, involves SMEs that already have banking relationships.

SMEs have reported a lack of trade finance among the major constraints to their business. This is a problem globally, but is more acute in developing countries where financial markets are underdeveloped. Figure 5 reports rejection rates by banks of trade finance proposals broken down by client type. This same differential rejection rate has been reported through all 3 years of the survey. 


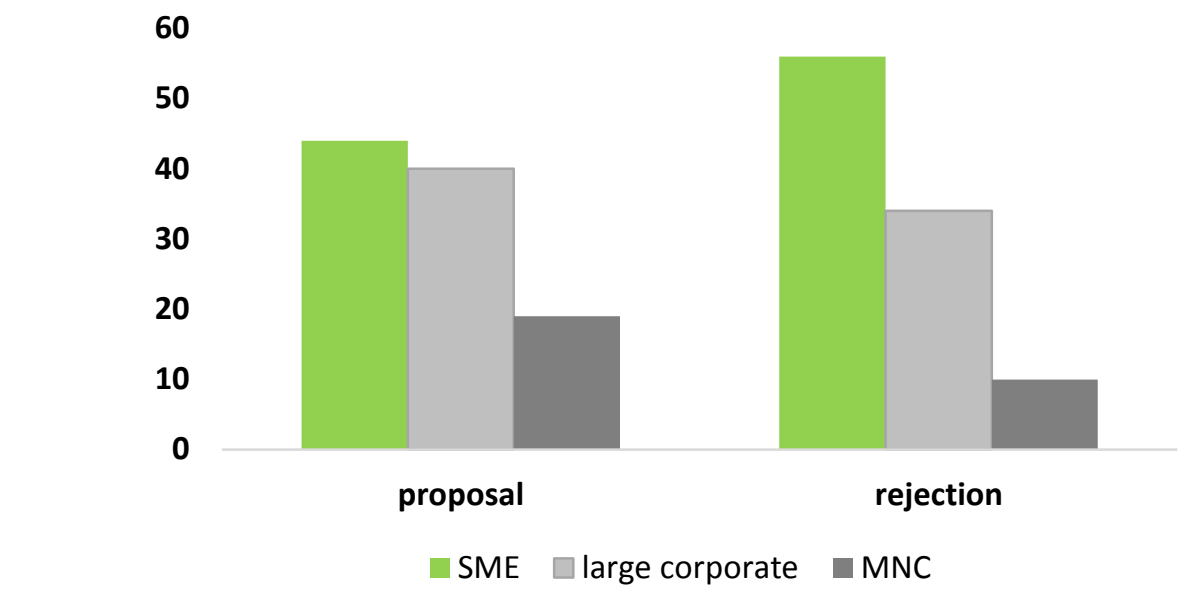

Source: ADB Trade Finance Gaps, Growth, and Jobs Survey 2016

There are clear transmission channels between a lack of trade finance and firm development. Market failures in financial markets fall disproportionally on SMEs. These firms are impacted more by the higher cost of screening and higher interest rates from banks (Stiglitz and Weiss, 1981; Beck and Demirgurç-Kunt, 2006).

Even in the absence of market failures, SMEs report less access to trade finance than larger firms. Firm level surveys echo this fact across countries. Even in developed countries where financial markets are deep, SMEs report lack of access. In the UK, 24\% of 2,664 exporting firms reported difficulty in accessing trade finance or credit insurance (BCC, 2016). In the United States, 32 percent of SMEs in the manufacturing sector and 46 percent of SMEs in the services sector considered the process of obtaining finance for conducting cross-border trade burdensome versus only 10 percent of large firms in manufacturing and 17 percent in services (USITC, 2010).

The literature offers some indication of the reasons driving SME access problems. SMEs are most likely to be associated with a troubled bank (Amiti and Weinstein, 2011), and credit constraints on smaller exporters are higher than those faced by larger firms, to the point of reducing the range of destinations for business or leading the SME to stop exporting altogether (Bricongne et al, 2012).

To what extent does lack of trade finance impact SMEs ability to link into trade? One survey of 3000 exporting firms from 52 countries reports that trade finance shortages affected both exports and turnover, as a result of foregone sales to foreign customers. Respondents noted that local financial sectors were often unable to support modern international transactions such as trade receivable financing $(C B I, 2013)$.

Developing country SMEs face the same obstacles as their counterparts in developed countries, such as recognition of creditworthiness, but they also face new challenges, such as smaller, more selective and perhaps less advanced local financial industries. This is often compounded by lack of access to knowledge and skills for handling trade finance instruments. 


\section{WHY DOES UNDERSUPPLY PERSIST?}

If trade finance gaps are indeed a market failure, then we'd need to show that the reasons for undersupply are affected by more than just risk. When banks were asked for the reasons they rejected trade finance applications, they stated the expected reasons related to collateral and risk. However, when asked a slightly different question: what factors were impeding their ability to extend additional trade finance, the results were indicative of higher costs resulting in consolidation away from perceived high risk segments of the market.

Figure 5. Constraints to additional supply of trade finance (\% bank respondents)

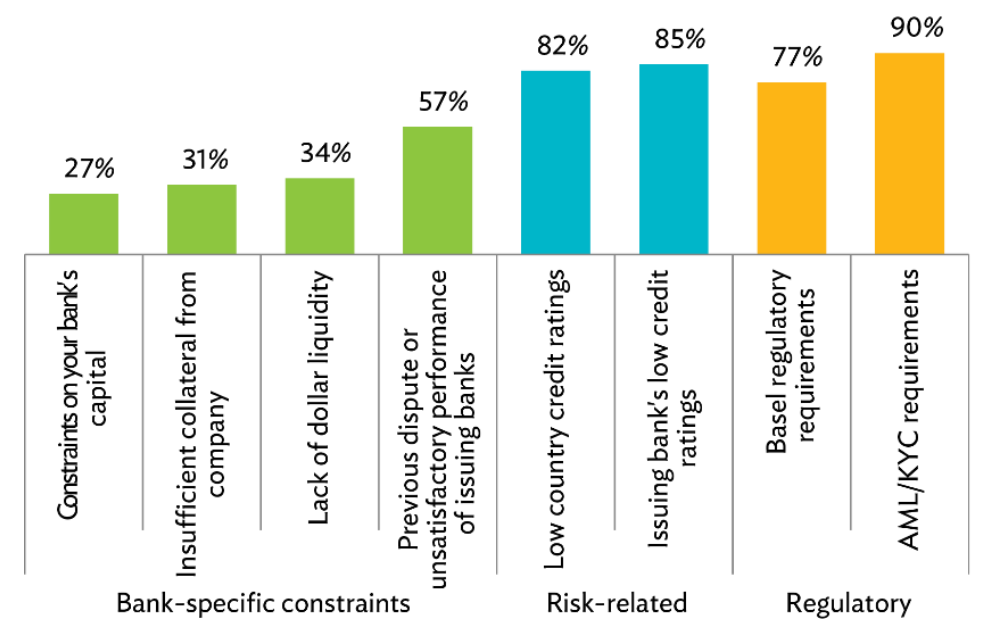

Source: ADB Trade Finance Gaps, Growth, and Jobs Survey 2016

In equilibrium, price should equate supply and demand, and would normally have some relation with the level of risk incurred. However, indications of prices for trade finance indicate interest rates with no relation with the level of risk. The situation at the low-end of the market may actually have worsened - paradoxically at a time when global markets have the appearance of being liquid. Liquidity appears to be chasing too few big clients, as global banks refocus their activities on core customers, while it does not flow to the lower stages of the markets (tier 2 or 3 banks and clients in developing countries). These impediments affect primarily SMEs, both in developed and developing countries, but are felt more strongly at the lowest levels of development.

Table 4. Africa trade credit pricing (annual interest rate)

\begin{tabular}{|l|l|l|l|l|}
\hline \multirow{2}{*}{$\begin{array}{c}\text { Country } \\
\text { (May 2011) }\end{array}$} & $\begin{array}{c}\text { Price range } \\
\text { (April 2014) }\end{array}$ \\
\hline & LOW & HIGH & LOW & HIGH \\
\hline Angola* & $60 \%$ & $65 \%$ & $65 \%$ & $70 \%$ \\
\hline Cameroon & $14 \%$ & $20 \%$ & $18 \%$ & $24 \%$ \\
\hline Congo & $22 \%$ & $26 \%$ & $22 \%$ & $26 \%$ \\
\hline DR Congo & $16 \%$ & $20 \%$ & $22 \%$ & $27 \%$ \\
\hline Ghana & $78 \%$ & $82 \%$ & $74 \%$ & $78 \%$ \\
\hline Kenya* & $39 \%$ & $49 \%$ & $39 \%$ & $49 \%$ \\
\hline Mozambique & $20 \%$ & $26 \%$ & $20 \%$ & $26 \%$ \\
\hline Senegal & $12 \%$ & $16 \%$ & $12 \%$ & $16 \%$ \\
\hline
\end{tabular}




\begin{tabular}{|l|l|l|l|l|}
\hline Sudan & $15 \%$ & $19 \%$ & $9 \%$ & $14 \%$ \\
\hline Tanzania & $10 \%$ & $13 \%$ & $25 \%$ & $35 \%$ \\
\hline Uganda & $14 \%$ & $16 \%$ & $16 \%$ & $18 \%$ \\
\hline Zambia & $13 \%$ & $20 \%$ & $13 \%$ & $20 \%$ \\
\hline
\end{tabular}

Note: Trade credits and their documentation differ from case-to-case and price ranges should therefore be considered as benchmark only. Price ranges are based on a monthly compilation of sources and analytics. Liquidity on most instruments is very limited and trading may not have taken places for some time.

*Spreads are corrected for inflation.

Source: Omni Bridgeway News, Debt Prices May 2011 and April 2014.

\section{Lack of trade finance as an obstacle to trade in Myanmar}

Myanmar is a new "frontier" country for trade. According to the local garment association, two new garment factories are opening every single day, from local, Chinese and Indian investors. New export-oriented investors also appeared in the agro-food and consumer products sectors. Still, the difficulties met by dynamic SMEs to finance imports and exports result in lost trading opportunities, which are symptomatic of constraints found in countries with similar levels of development: a lack of ability of the local banking sector to support the trade sector, lack of information by clients about available trade finance products, and lack of awareness by local regulators regarding appropriate regulation for trade finance products. For example, in Myanmar outdated regulations prohibit importers to pay foreign goods cash in advance, or local exporters to be paid after exportation. Moreover, foreign banks show only limited appetite to penetrate the domestic market, in part due to the current re-sizing of their global networks, and those willing to do so have been confined to foreign-owned customers by local law.

In such a difficult environment, Myanmar's main traders have so far resorted to second best solutions, mainly circumventing local laws by paying imports from bank accounts located overseas, or by opening letters of credit in off-shore centers such as Singapore and Hong-Kong, China, through brokers. Still, only the largest companies can afford to do so. New, small garment exporters do not hold any cash reserves to pay their suppliers from off-shore bank accounts, nor do they have the credit record for brokers to find foreign banks to open letters of credit. They can only rely on Myanmar's local banks, which have limited risk management capacity, still charge a $\$ 1,500$ on fee on any opening of a letter of credit and require a minimum of $30 \%$ collateral requirement. No open account facility is available in Myanmar, and trade credit insurance is not allowed. The lack of such efficient and affordable trade financing tend to relegate new exporters of garment and food products to downstream operations that require no buying of imports and no credit on export receipts. However, by accepting only a services fee for assembly operations, companies cannot move up the value chain to access higher quality and higher paying jobs.

The Government is reform-minded. Reforms in the financial sector are gradual, and it might indeed take some time for trade finance regulation to change, as well as for local banks to be more riskoriented, and propose a wider range of trade finance products locally at competitive conditions.

Externally, the Myanmar trading and financial sectors continue to suffer from some hang-over effect of international financial sanctions imposed by the international community in the past, and which 
have now been mostly lifted. The limited appetite by international banks to invest in poor countries at this point in time is also an issue mentioned above. Many global banks are in the process of reducing international networks and correspondent relationships, deleveraging balance sheets, and reducing costs. As compliance efforts are also increasing, the perception of reputational risk is at its highest on know-your-customer (KYC) and anti-money laundering (AML) rules. Despite efforts to upgrade standards, the local financial sector is still regarded to be behind requirements, which does not help international financial integration.

Myanmar currently receives technical assistance from the international community, on upgrading its trading and financial systems. The diagnosis on trade finance considerably improved recently, with joint missions and report by the International Trade Center, as well as the World Bank and the WTO (the later taking place with the framework of the Enhanced Integrated Framework).

Source: Myanmar's Trade Integration Study (DTIS), "Opening for Business", World Bank Group, pp.137-139.

There are a number of reasons that trade finance may be insufficient to meet demand in certain markets. The usual reasons include high risk, lack of regulations needed to offer different instruments, low demand, or low profit. However, to this list we would add two additional reasons that prevent markets from meeting demand, even as trade finance default rates are low and firms are willing to pay higher prices.

The first reason is related to the limited capacity of local markets to offer trade finance products. This includes both banks in developing countries as well as regional banks in the advanced markets (that know their clients well, but may not be used to dealing with cross-border transactions). The second reason is banks inability to establish correspondent relations globally.

\subsection{LOCAL BANK CAPACITY}

Local capacity to handle trade finance instruments efficiently depends on the development of the local financial system and the integration of local firms in regional or international trade. If liberalization of capital markets and the expansion of international trade have proceeded in parallel, there is a good chance that banks in a particular country or region have acquired the knowledge to finance and intermediate international trade transactions.

However, in the 2016 ADB survey, 37 percent of banks report that staff knowledge of trade finance was a limitation in their expansion of credit. Specifically, banks report that they are either not offering the most appropriate types of instruments - for example, simply allowing overdraft - for trade transactions, or rejecting them due to lack of knowledge about how to process (for example letters of credit).

There are two interrelated issues stemming from bank capacity. The first is from the bank-client relationship where shortfalls are not related in any way to the risk of the transaction. This is an issue for local or regional banks which may have closer relationships with clients, but less ability to service them as they demand more sophisticated instruments. This is precisely the problem MDB trade finance programs target. 
The second is the ability to comply with the regulatory requirements of confirming banks. At the transaction level, bigger banks are associated with greater volumes of proposed trade finance and higher rejection rates. However, cancelled correspondent relationships significantly differ by region (higher in Africa, Asia and Latin America) and type of bank (higher in banks that only operate in one country rather than regionally or globally).

The development of domestic financial systems in developing countries has generally increased access to working capital and trade credit for firms, in particular listed firms and reputable importers and exporters. However, in countries where the liberalization of capital account transactions has lagged international trade, trade credit extended directly between suppliers and customers have generally been dominant - at least in the lower end of markets - while larger transactions and contracts have generally been financed by ECAs or foreign banks re-insured by ECAs.

In such cases, lack of financing may at some point limit trade expansion, as either banks are barred by regulators to provide the necessary working capital to accompany the development of their client's trade activity (for example if foreign exchange regulation prescribe inter-bank borrowing with non-resident entities), or simply because they do not have the experience of handling trade finance instruments, which is hence left to the foreign customer/supplier's bank. Strengthening the capacity by local banks to provide adequate trade finance flows can be a real challenge in developing and least-developed countries.

Typically, in poor countries the largest bank is in a position to handle financing of international trade because it concentrates the limited know-how of the country in this field. It also attracts the most creditworthy and internationally-oriented local firms (those two factors may be closely related). And often it benefits from a regulatory advantage, for example the holding of a foreign exchange licence (when access to foreign exchange is restricted). At the same time, the lack of local capacity beyond these actors prevents and crowds out the emergence of new actors and traders which hence cannot find the appropriate finance to innovate and expand.

This highlights the multi-level nature of trade finance constraints faced by SMEs in developing countries and particularly Asia. Bank density in Asia and the Pacific is below the world average. This matters because banking concentration has been shown to have a particularly negative impact on SMEs (Ryan et al, 2014). Thus, options are limited by the lack of banking relationships. If the original bank rejects the transaction, SMEs - which are unlikely to have diversified banking relationships in low-density regions are unlikely to have a second option.

Firms use trade credit between themselves when they cannot obtain loans from financial institutions at affordable rates (Petersen and Rajan, 1997). In areas or countries where the perceived risk of lending for trade is assessed to be too high, banks ration credit to avoid charging excessive rates. Bank health influences the trade finance conditions offered to companies, and thus their export growth (Amiti and Weinstein, 2011). Hence, the availability of trade finance is largely influenced by the strength of international banks at any point in time.

\subsection{THE REGULATORY ENVIRONMENT}

The second reason that local bank capacity is not a sufficient indicator to understand trade finance is correspondent relationships. 
A large share of international trade is supplied by a relatively small group of globally-active international banks (BIS, 2014). In 2011, this group of about 40 banks accounted for some 30 percent of international trade finance, with local and regional banks supplying the remainder. This is reflective of the global distribution of banks as well. The table below illustrates the distribution and market power of large banks in a global population.

Table 5. Distribution of large banks regionally (2015)

\begin{tabular}{|c|c|c|c|c|c|c|}
\hline Region & $\begin{array}{l}\text { Number of } \\
\text { Companies }\end{array}$ & $\begin{array}{c}\text { Total Assets [CY } \\
\text { 2015] (\$mm) }\end{array}$ & $\begin{array}{c}\text { \% Global } \\
\text { Aggregates }\end{array}$ & $\begin{array}{l}\text { \# Large } \\
\text { Banks }\end{array}$ & $\begin{array}{c}\text { Total } \\
\text { Assets }(\$ \mathrm{~mm}) \text { - } \\
\text { Large Banks }\end{array}$ & $\begin{array}{l}\text { \% Regional } \\
\text { Aggregates }\end{array}$ \\
\hline Africa/Middle East & 289 & 4,508,309.9 & 0.03 & 30 & $2,463,901.9$ & 0.55 \\
\hline Asia/Pacific & 566 & $55,785,459.2$ & 0.38 & 133 & $50,027,508.3$ & 0.90 \\
\hline Europe & 943 & $51,698,756.5$ & 0.35 & 121 & $45,742,361.0$ & 0.88 \\
\hline LatAm and Car & 255 & $3,900,485.6$ & 0.03 & 18 & $2,444,607.8$ & 0.63 \\
\hline US and Canada & 4396 & $30,386,700.6$ & 0.21 & 66 & $25,110,720.9$ & 0.83 \\
\hline Global Aggregates & 6449 & $146,279,711.9$ & 1.00 & 368 & $125,789,100.0$ & 0.86 \\
\hline
\end{tabular}

Source: S\&P Capital IQ, 2016

The main trade finance banks are also dominant in other segments of financial services. Because in recent years they have been subject to more stringent capital and lending rules, they have recalibrated their balance sheets accordingly. Given their prevalence in international markets, their ability to provide trade finance globally and locally has been affected.

Whether their downsizing had a net negative effect on the ability of traders globally to receive credit and letters of credit confirmation is a debated issue. This depends on whether regional and local financial institutions have been able to capture the market shares left by global banks. There is anecdotal information according to which Asian banks have grown considerably, in line with the increasing flows of trade of their local customers.

In the process of deleveraging, some business models may have been more affected than others. Some trade banks focused on local presence, and hence expanded during the 1990's and 2000's through local establishment. Other banks increased their global network of correspondent banks without necessarily investing in local presence. Some banks did both. A 2016 survey of issuing banks in Bangladesh reports that limited transactions and high compliance costs was driving the increasing difficulties maintaining correspondent relationships (Bangladesh Institution of Bank Management).

Many banks claim that the increase the cost and complexity of $A M L / K Y C$ requirements after the financial crisis, combined with more stringent Basel rules, has resulted in their decisions to deleverage in particular markets. Concerns about regulatory environment by banks are not new. However, the number of financial institutions reporting it to be a significant impediment to expanding trade finance continues to rise. The ADB survey finds that $90 \%$ of respondents report that the costs of compliance with Anti-Money Laundering (AML) and Know-Your-Customers (KYC) requirements have affected their ability to extend trade finance. Basel III was also reported by $77 \%$ of banks as imposing a limit.

It is difficult to measure with precision the costs associated with AML. There are three indirect measures that provide some insight into the changing costs facing banks. First, the number of Suspicious Activity Reports (SARs) related to trade-based money laundering submitted to the US 
Department of the Treasury Financial Crime Enforcement Network have risen over time and particularly steeply in years following the global financial crisis. ${ }^{4}$ These are transactions which, under earlier regulatory regimes, would not have been flagged for any additional action.

Second, the cost of due diligence increases with the number and complexity of rules. Trade finance departments report that due diligence on a foreign financial institution in 2015 was around $\$ 75,000$ per year. The net revenue expected from doing business with such counterparty institutions would need to be commensurate if the cost was to be justified. For certain jurisdictions, due diligence costs are expected to be as high as $\$ 150,000$ by 2018 . This is further impacted by a lack of harmonization across jurisdictions.

Third, the volume of solutions being marketed in this area provides some insight into the demand for cost-reduction instruments. This includes everything from a KYC registry established by SWIFT, to efforts to move trade finance transactions onto the block-chain.

\section{DEVELOPMENT IMPLICATIONS: TRADE FINANCE AND INCLUSIVE GROWTH}

In light of the above, trade finance gaps may not improve in the short run. What does this mean for the firms that are affected? Intuitively, long term rationing of specific groups is a problem for inclusive economic development and trade expansion. However, the type of data needed for deep analysis of these issues is missing. We offer instead a look at the transmission channels that link the two. Using the access to finance literature as a guide, we ask three questions about firms that face unmet demand for trade finance - are they forgoing trade transactions? Are they misallocating internal capital? And, does employment differ in under-financed firms? Survey evidence provides insight into compensating behaviours that are not well understood in the literature. The 2016 ADB survey also allows us to highlight how women-owned firms differ from the general population of underserved firms. The reason for concern about lack of access to trade finance is particularly relevant in Asia and the Pacific. The region continues to pursue trade-driven economic growth. Regional supply chains continue to weave new exporters into established trade flows. And recently, as wages in PRC have risen, labor intensive industries, such as garment and apparel, have begun to shift to neighboring countries. Many of these countries - Bangladesh, Vietnam, and Cambodia - are those which are active in the trade finance support programs offered by multilateral development banks. This means that local financial sector is already struggling to meet demand for import and export finance.

For these reasons, there is a particular concern that SMEs in developing countries face lasting challenges in their integration into global trade, due to lack of finance. SMEs are the main source of employment in most countries. In developing countries, alternatives to traditional bank financing such may simply not exist. Trade credit insurance may also not be available, and the legal framework for factoring may not be in place either. As a result, when banks reject requests for trade finance, SMEs may be left with no alternative but to pay its trade cash, go informal or forego the transaction as we will show in sections that follow.

\subsection{TRADE OUTCOMES}

The most common transmission channel is the most straightforward: trade finance impacts development via its role in promoting trade. Trade flows are positively correlated with GDP growth,

\footnotetext{
${ }^{4}$ see e.g. https://www.fincen.gov/resources/advisories/fincen-advisory-fin-2010-a001
} 
and therefore instruments that reduce the risk of trade will improve flows linked to higher-risk markets and clients. Earlier sections used data from liquidity shocks to link trade finance to trade flows. It follows that where trade finance transactions are rejected, trade activities related to those transactions will be negatively impacted. Surveys of firms and banks introduce some nuance to this relationship.

First, the ADB survey indicates that shortfalls result in foregone trade. 71\% of SMEs report that when a bank declines to finance a trade transaction, they do not seek alternative financing for that transaction. While some of these transactions are then self-financed, we can assume that some proportion of them do not go forward. It may be that these were low quality transactions. In the second lesson, we look a little closer at the data to explore whether this is the case.

Second, the high rejection rates faced by SMEs may be screening out potentially viable transactions. Firms reported reasons for rejection of their proposals, which suggest that relationships between banks and SMEs in both Africa and Asia are underdeveloped and therefore potentially profitable transactions go unfinanced. By the numbers: Both African and Asian SMEs report similar reasons behind trade finance rejections - insufficient collateral or guarantee (33\% v. $25 \%)$ and lack of existing business relationship $(13 \% \vee 17 \%)$. This suggests that even where firms are able to fulfill documentary requirements, and submit a sound proposal, they are not receiving finance.

Finally, rationed firms may scale their trade portfolios more slowly. Firms that have secured formal bank-intermediated finance should be able to access finance on better or cheaper terms in the future. In addition, trade finance is critical to introduce and scale up export sales (Li and Wilson, 2009) show that trade finance increases the propensity of SMEs to become exporters. At early levels of trade, trade costs may be absorbed internally. But as exports increase in volume trade finance becomes critical. The firms under consideration in this paper are formal, active in trade, and have already secured banking relationships. These characteristics suggest that among the universe of SMEs, they are already the most productive (LaPorta and Shleifer, 2014) and likely to promote growth (Torm and Rand, 2012). It may also signal that the firm has reached a certain level of financial management and capacity. Trade finance may indicate their exploration of new products or markets.

\subsection{EMPLOYMENT}

A second transmission channel that has been raised in the trade finance discussion is employment. The underlying assumption for the global focus on SME finance is that by promoting SME trade finance, employment will increase. This is backed up by two empirical regularities. First, SMEs employ the majority of the global workforce. The median employment share of SMEs across countries is $67 \%$ (Ayyagari et al, 2011). Second, exporting firms grow faster than non-exporters in terms of number of employees (Dinh et al, 2010). Intuitively, it follows that by enabling SMEs to export more, employment will expand.

But empirically, this link is indirect and not easy to establish. Endogeneity is an issue since bigger firms get more finance, thus rationed firms have lower employment. The literature offers some evidence about the trade finance-employment links from episodes of credit crunches. Specifically that employment levels at firms associated with unhealthy banks fall more than those at firms 
associated with healthy banks (Chodorow-Reich, 2014). However, when shortfalls are long-term, it is tricky to tie shortfalls to employment outcomes.

More convincing is the argument that SMEs which receive trade finance are likely to produce higher quality employment. This results from both the selection of firms into trade finance and also the standards faced by firms in international markets. SMEs in developing economies are often informal. Informal firms, by definition, are not required to follow labor laws. SMEs in the formal sector are at least nominally subject to domestic laws.

Woman-owned firms hire more women. Yet they are also among the most strongly rationed firms. Thus we can also conclude that improving trade finance to this particular group can also expand employment among women.

\subsection{CAPITAL ALLOCATION}

A third impact comes from the inefficient choices rationed firms make when trade finance is persistently low. Medium sized firms often have an undifferentiated management structure (Bloom and van Reenan, 2007). The lack of internal capacity to explore financial options contributes to inefficient choices in capital allocation. The ADB survey data contributes two different angles to the suggestion that trade finance shortfalls contribute to inefficient capital allocation. The first comes from questions about what they did following final rejection. 55\% of firms report attempting to finance the same transaction through another provider.

Figure 6 : How firms proceed when a transaction was rejected (\% responses)
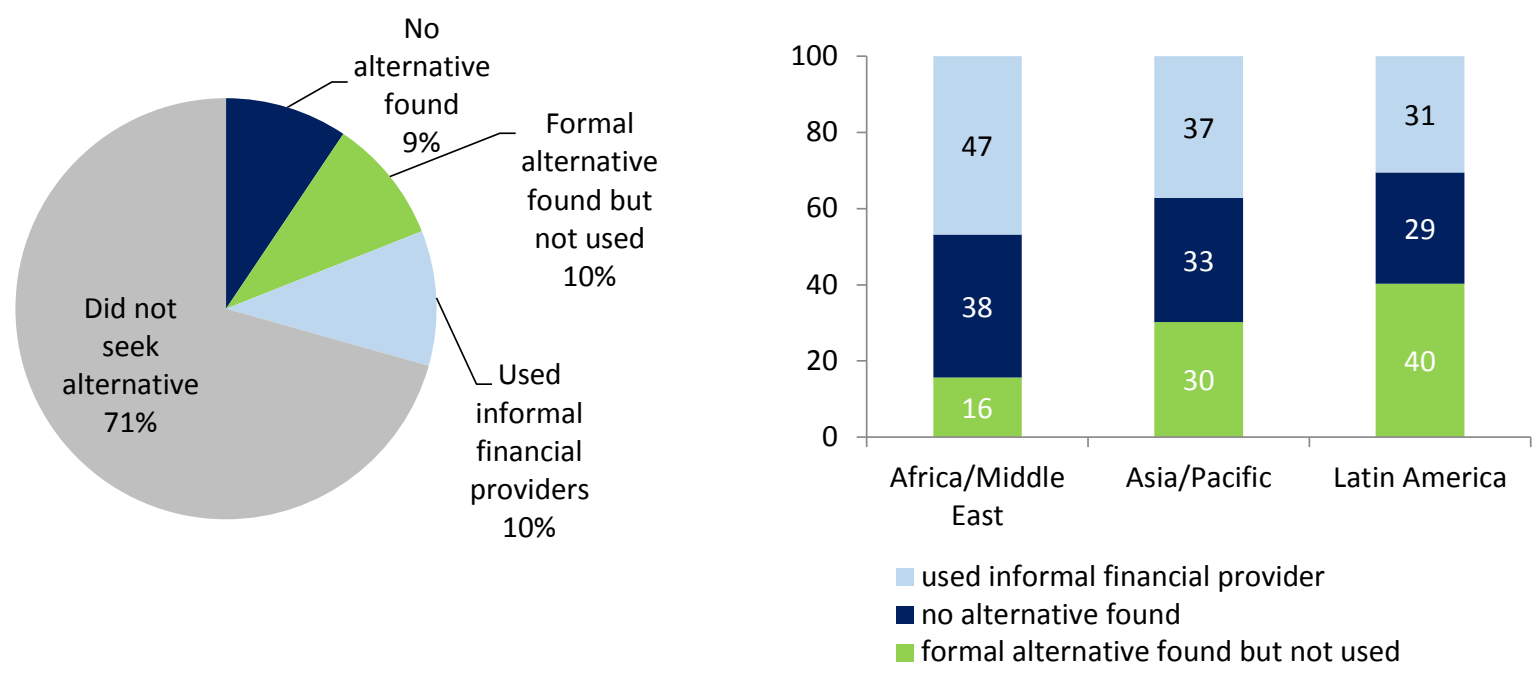

Source: ADB Trade Finance Gaps, Growth, and Jobs Survey 2016

Of firms that tried to find alternative financing, $28 \%$ resulted in a costly agreement to cover the transaction, and $19 \%$ resorted to the informal sector, which suggests that there was enough potential value in the transaction that the firm was willing to borrow informally. Firms were most likely to turn to informal providers in Developing Asia and Sub-Saharan Africa. This also suggests that firms adjust along different margins as they gain information about their perceived riskiness. In the case of financing using informal providers, firms are not dropping out of exporting due to shortfalls, they are simply identifying a more suitable lender. 
A second angle of the capital allocation question comes from a hypothetical question about how firms would allocate additional capital if trade finance increased. Firms in emerging markets often do not have many formal options where they are rejected by their primary institution, particularly in Asia and Africa where bank density is low. In addition, some recent work on the issuance of dollar bonds shows that firms in emerging economies tend to borrow for financial risk-taking, not because they have run out of internal capital (Bruno and Shin, 2015). In the ADB survey, firms reported that if they received more trade finance, the most frequent response was that they would invest in new businesses. Since trade finance is not directly used for investment, this implies that they are using capital to finance transactions that might otherwise be put to more productive use.

\subsection{SOCIAL IMPACT}

To these we add the transmission channel of inclusion. There are social benefits from an equitable distribution of trade finance among small and large firms, among urban and rural firms and among female and male-owned firms. There are also social benefits from extending trade finance to markets where it is scarce. The ADB survey allowed firms to self-identify as being a women-owned firm. This allows us to see the particular challenges faced by these firms and understand how trade finance impacts their ability to contribute to the economy. The particular issues faced by women-led firms have been alluded to in the literature, but hard data is difficult to come by. The IFC has suggested that only $10 \%$ on women led firms have access to formal finance. In the ADB survey, $100 \%$ of firms in this population have access to formal finance, but only $18 \%$ of women-led firms report having sufficient trade finance. Woman-owned have a number of distinguishing characteristics in their access to trade finance. As expected, there are smaller than the median firm. They are also more dependent on trade finance for their ability to trade and also more likely to be rejected by a financial institution. However women-owned firms also exhibit some interesting characteristics that we cannot adequately explain with the data. For example, they are more resilient to rejections. That is, they are more likely to look for alternative sources of financing once they are rejected. In addition, they are more likely to use digital financial solutions. This is unusual given what we know about the gender digital divide.

Table 6. Characteristics of woman-led firms

\begin{tabular}{|r|cc|}
\hline Median employees & $\begin{array}{c}\text { women-led } \\
\text { firms }\end{array}$ & $\begin{array}{c}\text { Non-women } \\
\text { led firms }\end{array}$ \\
\hline $\begin{array}{r}11 \\
(55 \% \text { women) }\end{array}$ & $\begin{array}{r}16 \\
(37 \% \text { women })\end{array}$ \\
$\begin{array}{r}\text { tself-reported) } \\
\text { trade) }\end{array}$ & $21 \%$ & $14 \%$ \\
Dependion rates for trade finance & $50 \%$ & $43 \%$ \\
\hline Likelihood to seek alternatives & $41 \%$ & $35 \%$ \\
\hline Proportion using digital finance & $26 \%$ & $6 \%$ \\
\hline
\end{tabular}

Source: ADB Trade Finance Gaps, Growth, and Jobs Survey 2016 
As shortfalls persist, the development community has acknowledged that access to trade finance is a development problem. However, existing measures have achieved only partial success, which is in part the result of difficulties in targeting interventions at a multidimensional problem. There have been a number of activities aimed at addressing the development shortfalls that result from trade finance gaps. One intervention that has received an increasing amount of attention is fintech. While not traditional trade finance, it has the goal of servicing traditionally underserved, but potentially profitable client segments. Does survey evidence support their idea that this will solve trade finance gaps in the short to medium run?

\section{IS DIGITIZATION THE SOLUTION?}

Trade finance is in the middle of a period of intense disruption. Digitization and disintermediation are proceeding at a breakneck speed. Yet this is occurring at a time where the digital divide threatens to leave the poorest and least connected populations even further behind. How will unmet demand be impacted? We look at two angles of this question. First, does digitization in banks alleviate the reasons for bank undersupply? And second, will fintech impact left-out groups disproportionately? We find that in both cases the potential is strong for digitization to shrink trade finance gaps. However, in 2015, the impact remains marginal.

\subsection{DIGITIZATION OF TRADE FINANCE OPERATIONS IN BANKS}

Trade finance is being disrupted by technology. Banks are digitizing as a way to reduce costs and recapture crushed profit margins that were associated with the financial crisis, both policy based (regulatory changes and quantitative easing) and non-policy based (deleveraging, more competitive environment). Firms are also moving online and ecommerce is increasingly introducing small firms to export markets. A feature of both of these trends is the rise of fintech that offer new ways to fund cross-border commerce in developed and developing countries alike. But is any of this changing the fact that small firms and women-led businesses lack access to finance?

Trade finance services are becoming increasingly automated to enable financing to be fully integrated with the global sourcing and logistics of manufacturing activities across countries. The question is whether automation translates to more finance for traders. Recent years have seen global banks and multinational corporates put in place online portals which support the expansion of open account transactions, and provide credit at key points of the supply chain. ${ }^{5}$ At the same time, the expansion of ecommerce has increased the amount of trade paid cash-in-advance, since ecommerce requires upfront payments. Individuals or companies with lower market power have no choice other than cash/card-in-advance. Few platforms actually provide trade finance, although working capital loans to preferred firms are increasingly common and in some cases these are specifically tied to exports.

Digitization of trade finance operations within financial institutions can reduce the costs and time intensity of trade finance. ${ }^{6}$ Banks that are global or regional in scope have reported rates of

\footnotetext{
${ }^{5}$ Web portals provide for electronic preparation of documents and exchange, the reconciliation of purchase orders and invoices and the actual payment, the on-line provision of credit by banks and insurance of such credit by private sector insurer, all of them being linked within a single electronic system.

${ }^{6}$ This enables bankers and traders to be more cost-effective and competitive. It also promotes information exchange among suppliers, customers and their financial intermediaries on the transaction (including trade documents), thereby creating a sense of security and a reduction of risk across the supply chain. In that way,
} 
digitization above $45 \%$. While, expectedly, only a quarter of smaller and issuing banks report digitization at the higher end of the distribution.

Figure 7. Reported degree of digitization in banks (by size)

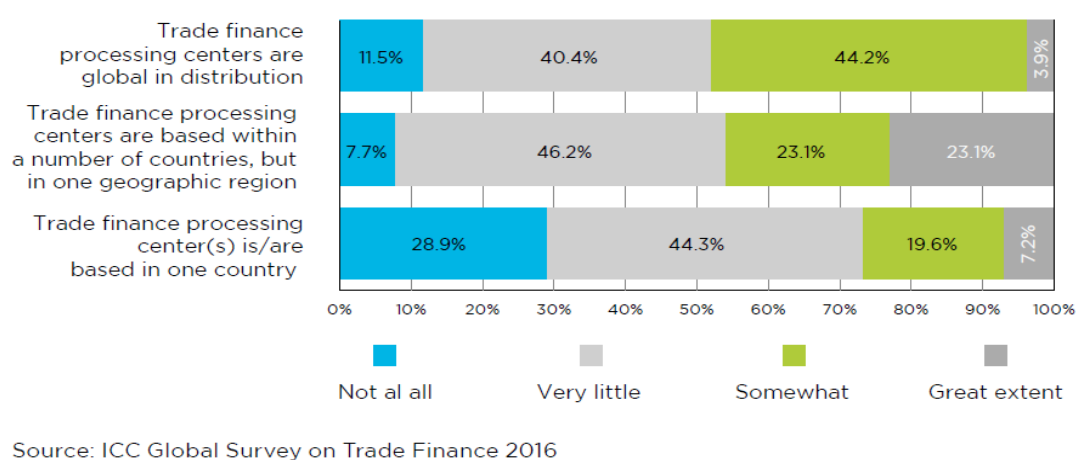

Source: ICC Global Survey on Trade Finance 2016

\subsection{FINTECH AND RATIONED FIRMS}

Digitalization of finance does not necessarily mean more trade finance. It may mean cost reduction for providers of finance, greater transparency of transactions for parties to the transactions (hence improving the security of the transaction), and a reduction of transaction costs (to the extent that the traders, and not only the bankers, benefit). Fintech solutions may render the management of trade finance solution easier, and optimize the use of working capital.

Firms which experience trade finance shortfalls resort to second-best solutions including by selffinancing trade (and hence using scarce cash resources). For traders which are subject to fierce competition in international markets, any inefficiency in the terms of payment affects their competitiveness. The ADB 2016 survey offers a number of important insights into the use of fintech solutions by rationed populations. First, $70 \%$ of firms globally are unfamiliar with any fintech instruments. Second, of firms that have heard of fintech, uptake rates are near $30 \%$ across developing regions including Africa, Asia and Latin America. This suggests that information sharing is one of critical next steps to employing fintech as a strategy to offer finance to rationed populations.

Figure 8: Recognition and use rates of fintech

customers feel more comfortable to offer early payments, suppliers can provide discounts, and in the end such suppliers can permanently reduce prices when contracts are renegotiated. Also, on-line and supply-chain trade financing tends to boost the banks' role in open account transactions, which are more secure than in the past, at the detriment of letters of credit, which are less used in North-North trade. 


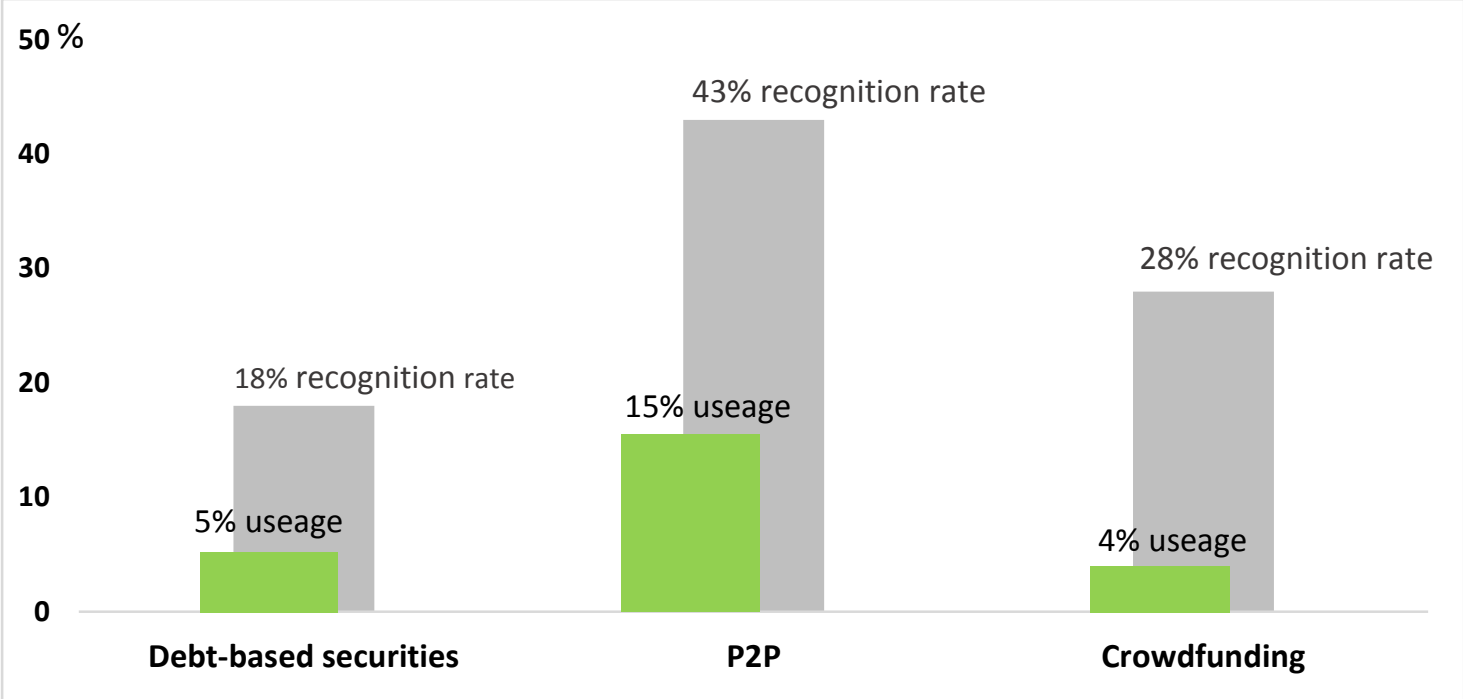

Source: ADB Trade Finance Gaps, Growth, and Jobs Survey 2016

The ADB survey data highlights some important characteristics of fintech. Specifically, that users of fintech are a distinct group. Firms using fintech solutions are more likely to report higher rejection rates for their trade finance proposals to banks, have a much higher propensity to pursue alternatives once rejected, and are more likely to be women-led. Beyond these features, there are no distinctions by firm size, sector, trade dependence or trading partners.

\section{Figure 9: Characteristics of fintech users vs. non-users}

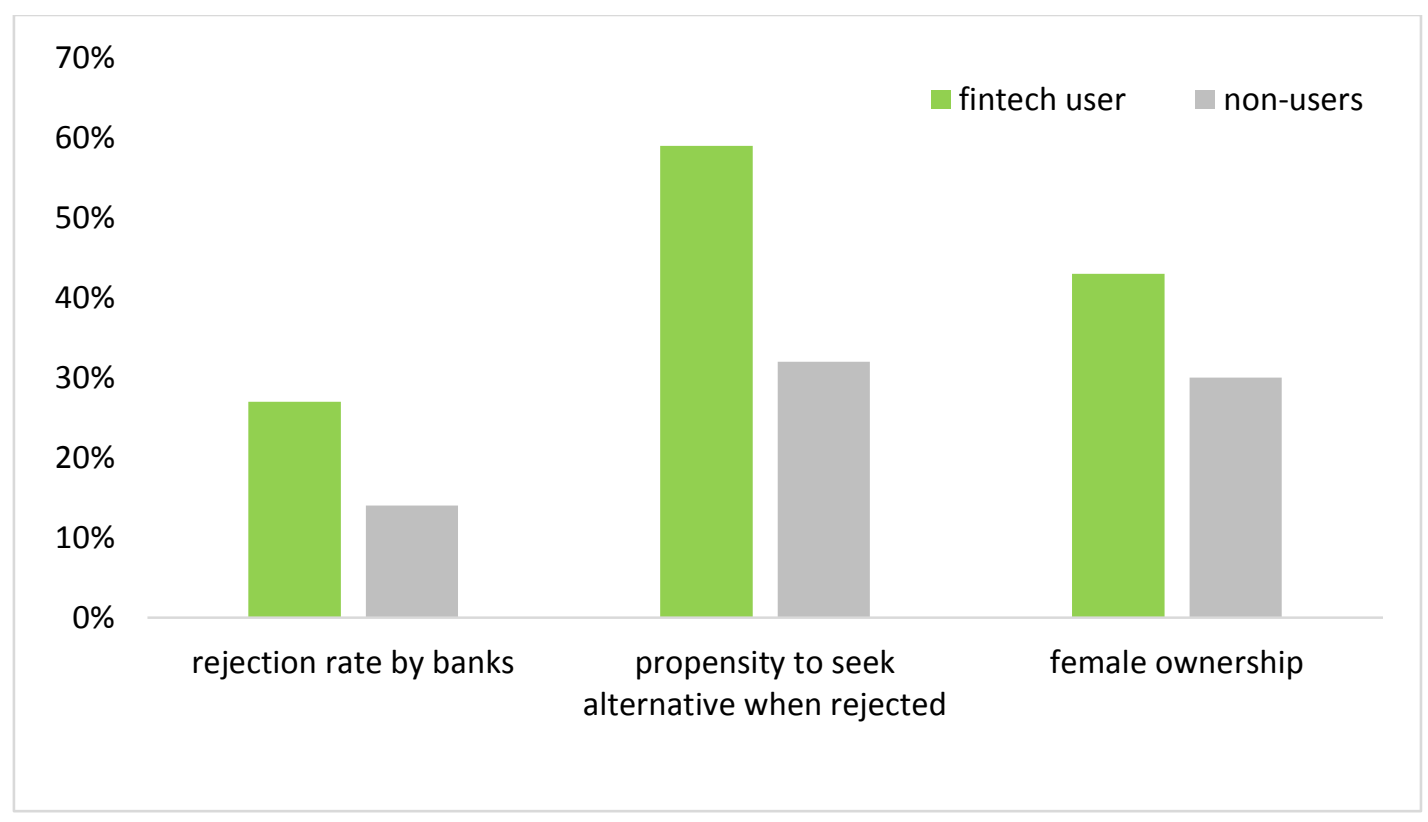

Source: ADB Trade Finance Gaps, Growth, and Jobs Survey 2016 
The policy problem generated by market changes is that the technology gap might increase the risk of marginalization of poor countries in trade transactions. While market analysts believe that letters of credit will remain the backbone of trade in South-South transactions, access to liquidity will be easier for developing countries that have access to the technology network and can work with international banks and suppliers on the basis of the new efficiency standards of the markets. Trade finance operators in developed countries are likely to be more inclined to allocate the existing amount of working capital to counterparts in developing countries that can participate in reducing the cost of transactions by providing a maximum of information in the required electronic format.

\section{CONCLUSION}

Many of the challenges faced by banks and firms in connecting with trade finance originated in the global financial crisis. Yet, today, years after the end of the financial crisis, and in a period in which the slowdown of trade flows should lead to a reduction of the demand for trade finance - gaps persist in certain emerging economies and client segments.

This paper sought to clarify the reasons for the persistence of trade finance gaps. The market failure argument provides insight into why the cost of trade finance is not consistent with the risk of providing it. However, this explains only part of the problem. Additional factors include asymmetry of information about risk levels of certain clients and markets, and lower profits.

We also introduced information about how rationed populations respond to unmet demand. In particular, we focus on SMEs with the objective of extending the access to finance debate beyond the initial question of why SMEs are often unbanked. We highlight that SME access to finance is not resolved once they become banked and that this is a particular problem for women-led firms. Firms either forego trade transactions or adopt second-best solutions. In both cases, the unavailability of trade finance limits the growth and employment potential of this class of firms.

Efforts at the multilateral level will be critical to addressing these issues. In the current risk and regulatory environment, financial institutions are continuing to consolidate away from low-profit and low-volume segments. Fintech is making progress, but not in a way that is yet addressing the core of the problem. 


\section{BIBLIOGRAPHY}

African Development Bank (AfDB) (2014), "Trade finance in Africa", Abidjan: African Development Bank.

Ahn, J., Amiti, M., and Weinstein, D. (2011), "Trade Finance and the Great Trade Collapse", American Economic Review, Vol 101 (3), pp. 298-302.

Amiti, M. and Weinstein, D. (2011), "Exports and Financial Shocks", The Quarterly Journal of Economics (2011), Vol. 126 (4), pp. 1841-1877.

Antràs, P. and Foley, F. (2011), "Poultry in Motion: A Study of International Trade Finance Practices", NBER Working Paper no. 17091.

ADB (2014), "ADB Trade Finance Gaps, Growth, and Jobs Survey ", ADB Brief No. 25, authored by A. DiCaprio, S. Beck, J. Daquis, Manila: Asian Development Bank.

ADB (2016), "2016 Trade Finance Gaps, Growth, and Jobs Survey", ADB Brief No. 64, authored by A. DiCaprio, S. Beck, F. Khan and Y. Yao, Manila: Asian Development Bank.

Auboin, M. and Engemann, M. (2014), "Testing the Trade Credit and Trade Link: Evidence from Data on Export Credit Insurance", Review of World Economics 150 (4), 715-743.

Ayyagari, M., Demirguc-Kunt, A., and Maksimovic, M., (2011), "Small vs. Young Firms across the World: Contribution to Employment, Job Creation, and Growth", World Bank Policy Research Working paper 5631, Washington D.C.

Berman, N. and Héricort, J. (2010), "Financial factors and the margins of trade: Evidence from crosscountry firm-level data", Journal of Development Economics, Vol. 93, pp. 206-217.

BIS (2016), Correspondent Banking, Basel: BIS.

Bloom, R., and Van Reenen, J. (2007), "Measuring and Explaining Management Practices Across Firms and Countries", The Quarterly Journal of Economics, 122(4): 1351-1408.

Bricongne, JC.,Fontagné, L.,Gaulier, G.,Taglioni, D., and Vicard, V. (2012), "Firms and the Global Crisis: French Exports in the Turmoil", Journal of International Economics, 87: 134-146.

Bruno, V., and Shin, H.S. (2015), "Cross-Border Banking and Global Liquidity", Review of Economic Studies, 82 (2), 535-564.

Chodorow-Reich, G. (2014), "The Employment Effects of Credit Market Disruptions: Firm-level Evidence From the 2008-2009 Financial Crisis," Quarterly Journal of Economics, Vol. 129, Issue 1, pp. 1-60.

Chor, D., and Manova, K. (2012), "Off the Cliff and Back? Credit Conditions and International Trade During the Global Financial Crisis", Journal of International Economics, Vol. 87, pp. 117-133. 
Clementi, G. and Hopenhayn, H., (2006), "A Theory of Financing Constraints and Firm Dynamics", Quarterly Journal of Economics, 121 (1): 229-265.

Dabla-Norris, E. Ji, Y., Townsend, R. and D. FilizUnsal (2015), "Identifying Constraints to Financial Inclusion and Their Impact on GDP and Inequality: A Structural Framework for Policy", IMF Working Paper 15/22, Washington D.C.

Dinh, H., Mavridis, D., and Ngyuen, H. (2010), "The Binding Constraint on Firm's Growth in Developing Countries," World Bank Policy Research Working Paper No. 5485.

Fisman, R., and Love, I. (2003), "Trade Credit, Financial Intermediary Development, and Industry Growth", Journal of Finance, Vol. 58, No. 1, pp. 353-374.

Freund, C. (2009), "The Trade Response to Global Downturns: Historical Evidence." Policy Research Working Paper No. 5015, World Bank, Washington, DC.

lacovone, L. and Zavacka, V. (2009), "Banking Crises and Exports: Lessons from the Past", Policy Research Working Paper Series 5016, The World Bank.

ICC (2013), "Global Risks - Trade Finance Report 2013", Paris: ICC Banking Commission.

ICC (2015), "Trade Register Report", Paris: ICC Banking Commission

IMF (2016), "The withdrawal of Correspondent Banking Relationships: A Case for Policy Action", Staff Discussion Note 16/06, Washington D.C.

Korinek, J., J. Le Cocguic and P. Sourdin (2010), "The Availability and Cost of Short-Term Trade Finance and its Impact on Trade", OECD Trade Policy Papers, Paris.

LaPorta, R. and Shleifer, A. (2014), Informality and Development, Journal of Economic Perspectives, 28(3): 109-126.

Li, Y., and Wilson, J. (2009) "Trade Facilitation and Expanding the Benefits of Trade to SMEs," Note for Regional Policy Forum on Trade Facilitation and SMEs in Times of Crisis, Beijing China.

Petersen M., Rajan R, (1997) "Trade Credit: Theories and Evidence" Review of Financial Studies, 3: 661-691.1997.

Ryan, R., O'Toole, C., McCann, F. (2014) "Does Bank Market Power Affect SME Financing Constraints?" Journal of Banking and Finance, Vol 49, pp. 495-505.

Torm, N.E. \& Rand, J., (2012), "The informal sector wage gap among Vietnamese micro-firms", Journal of the Asia Pacific Economy, 17(4), 560-577.

Stiglitz, J., and Weiss, A. (1981), "Credit rationing in markets with imperfect information", American Economic Review 71(3): 393-410. 
USITC (2010), "Small and Medium-Sized Enterprises: Characteristics and Performance" Investigation No. 332-510, USITC publication No. 4189 